\title{
Tooth Loss Associated with Abnormal Electrocardiographic Findings in Octogenarians
}

\author{
Yutaka Takata', Toshihiro Ansai², Shuji Awano², \\ Kazuo Sonoki ${ }^{1}$, Sumio Akifusa ${ }^{2}$, Masayo Fukuhara', \\ Masanori Wakisaka ${ }^{1}$ and Tadamichi Takehara ${ }^{2}$ \\ ${ }^{1}$ Division of General Internal Mnedicine, Department of Health Promotion, \\ ${ }^{2}$ Division of Community Oral Health Science, Department of Health Promotion, \\ Kyushu Dental College, Kitakyushu, Japan \\ E-mail: yutaka@kyu-dent.ac.jp \\ Received July 25, 2005. \\ Accepted August 26, 2005.
}

\begin{abstract}
Since little is known about regional differences of tooth loss as a predictor of coronary heart disease (CHD), we evaluated the association of abnormal electrocardiographic (ECG) findings with toothloss. Of the 1282 residents, aged 80-year-old, of 9 communities selected in Fukuoka Prefecture, 697 subjects participated in our study. An oral examination determined whether each tooth was present or absent and an assessment of community periodontal index for each tooth was performed. Twelve-lead ECG recording, blood pressure (BP) measurement, and blood sampling was done. Individuals who lost the lateral incisor or 1st molar in the right maxilla, central incisor or cuspid in the left maxilla, or 2nd premolar or 1st molar in the left mandible had a higher prevalence of ST-segment depression, T-wave abnormalities, or the combination than those with a preserved corresponding tooth. This relationship between tooth loss and abnormal ECG findings was significant even after adjustment for gender, smoking, toothbrushing, regular doctor visits, serum cholesterol, serum glucose, systolic BP, diastolic BP, and body mass index, indicating that tooth loss at these specific sites is an independent predictor of an abnormal ECG in an 80-year-old population. Tooth loss in specific areas may be an independent predictor of abnormal ECG findings in an 80-year-old population; specific tooth loss and periodontal disease may be independent risk factors for CHD.
\end{abstract}

Key words: ECG/Tooth loss/Dental/Coronary heart disease/Elderly 


\section{Introduction}

Recent reports have suggested that periodontal disease may be a risk factor for coronary heart disease $(\mathrm{CHD})^{1-8}$. In a 7-year prospective study of 214 individuals with proven coronary artery disease (CAD), dental infection was a significant predictor of coronary events when controlling for other coronary risk factors ${ }^{9}$. Another study $^{10}$ found an increased risk of fatal CHD in patients with severe gingivitis or edentulousness, with relative risks of 2.15 and 1.90, respectively. Meta-analysis has similarly demonstrated that the periodontal disease is a significant risk factor for $\mathrm{CHD}$ and coronary events ${ }^{11}$. We recently found that the number of tooth loss may be an independent predictor of abnormal ECG findings in octogenarians ${ }^{12}$.

ST depression or T-wave abnormalities on resting 12-lead electrocardiography (ECG) are predictors of $\mathrm{CAD}^{13-15)}$, cardiovascular disease ${ }^{14,15)}$, cardiac death ${ }^{16)}$, death from all causes ${ }^{14,16-18)}$, sudden death ${ }^{19)}$, and other coronary events ${ }^{18)}$. Although studies have suggested that periodontal disease and tooth loss are risk factors for CHD, little is known about whether specific tooth loss is associated with abnormal electrocardiographic findings in elderly individuals, and in this study, we evaluated that relationship.

\section{Patients and Methods}

\section{Subjects}

In 1998, 1282 individuals who were 80 years old resided in the 3 cities (Buzen, Yukuhashi, and Munakata), 4 towns (Katsuyama, Tuiki, Toyotsu, and Kanda), 1 village (Shinyoshitomi), and 1 ward (Tobata of Kikakyushu City) of the Fukuoka Prefecture, Japan. All of these individuals were invited to participate in this study, and 697 individuals (277 male, 420 female) accepted inclusion in this study. The study was approved and individual rights were protected by the Human Investigations Committee of Kyushu Dental College; informed consent was obtained from all individuals.

Oral examination

We performed an oral examination as recommended by the World Health Organization (WHO), including an assessment of the community periodontal index (CPI: group 0, no signs of periodontal disease; group 1, gingival bleeding on probing; group 2, supra- or subgingival calculus; group 3, pathologic periodontal pockets 4 to $5 \mathrm{~mm}$ in depth; group 4 , pathologic periodontal pocket $\geq 6 \mathrm{~mm}$ in depth). Pocket depths were measured using a manual periodontal probes, and the presence of bleeding was determined. We also examined whether each tooth was present or absent.

Electrocardiography (ECG)

Twelve-lead ECG recording and blood pressure (BP) measurements were performed in the supine position. Blood sampling was performed in the seated position. The 12-lead ECG was recorded using a standard electrocardiograph (Cardisuny Alpha 500BX, Fukuda ME Kogyo Co., Tokyo, Japan) equipped with an automated analysis system. Specific criteria 
were used to identify ECG abnormalities. ST-segment depression was defined by horizontal or downsloping depression $>0.1 \mathrm{mV}$ in lead I, II, aVL, aVF, or V1 to V6 or by upsloping depression $>0.2 \mathrm{mV}$ in lead I, II, aVL, or V1 to V6. T-wave abnormalities were defined by a $\mathrm{T}$-wave amplitude/ $\mathrm{R}$-wave ratio $<1 / 10$ with an $\mathrm{R}$-wave amplitude $\geq 1.0 \mathrm{mV}$ or a negative T-wave in lead I, II, aVL, or V1-V6.

Statistical analysis

All data are reported as the mean $\pm S D$. Differences in mean values between two groups were analyzed using Student's $t$ test and for 3 or more groups by analysis of variance. Categorical variables were compared using the chi-square test. Logistic regression was used to determine which categorical factors were independent predictors of abnormal findings on ECG. All statistical analyses were performed using StatView 5.0 (SAS Institute Inc., Cary, NC). Results were considered significant with $\mathrm{P}<0.05$.

\section{Results}

Tooth loss for each site is shown in Table 1. Loss of cuspids and retention of the third molar were the least in each jaw. More than half of teeth were absent for each position. The mean number of remaining teeth was $8.0 \pm 8.9$ for all subjects. In the 648 individuals with 12-lead ECG recordings, ST-segment depression was observed in 63 patients (9.7\%) and $\mathrm{T}$-wave abnormalities (inverted $\mathrm{T}$ or flat $\mathrm{T}$ waves) in 199 patients (30.7\%). A combination of ST-segment depression or abnormal T-waves was present in 205 patients (31.6\%). Prevalences of abnormal ECG findings based on whether each tooth was present or absent in the right or left maxilla or the left mandible are shown in Table 2. Individuals with loss of the lateral incisor in the right maxilla had a higher prevalence of ST-segment depression than those with retention of this tooth, while those with loss of the 1st molar had a higher prevalence of T-wave abnormalities or the combination of ST-segment depression and/or $\mathrm{T}$-wave abnormalities. The prevalence of ST-segment depression, T-wave abnormalities, or their combination was higher in individuals without a central incisor in the left maxilla than those with this tooth. Similarly, Twave abnormalities were more preva-

Table 1 Number of losses for the corresponding tooth

\begin{tabular}{lcc}
\hline \hline & $\begin{array}{c}\text { Right maxilla } \\
(\mathrm{n}=693)\end{array}$ & $\begin{array}{c}\text { Left maxilla } \\
(\mathrm{n}=693)\end{array}$ \\
\hline Third molar & 670 & 669 \\
Second molar & 562 & 550 \\
First molar & 560 & 551 \\
Second premolar & 509 & 534 \\
First premolar & 504 & 503 \\
Cuspid & 448 & 461 \\
Lateral incisor & 492 & 503 \\
Central incisor & 520 & 502 \\
\hline & Right mandible & Left mandible \\
\hline Third molar & 642 & 654 \\
Second molar & 564 & 580 \\
First molar & 575 & 588 \\
Second premolar & 513 & 523 \\
First premolar & 434 & 442 \\
Cuspid & 355 & 355 \\
Lateral incisor & 427 & 430 \\
Central incisor & 464 & 452 \\
\hline
\end{tabular}


Table 2 Correlation between ECG abnormalities and the presence or absence of each tooth

\begin{tabular}{|c|c|c|c|}
\hline & $\begin{array}{l}\text { ST-segment } \\
\text { depression }\end{array}$ & $\begin{array}{c}\mathrm{T} \text {-wave } \\
\text { abnormalities }\end{array}$ & $\begin{array}{l}\text { ST depression } \\
\text { and/or T-wave } \\
\text { abnormalities }\end{array}$ \\
\hline \multicolumn{4}{|c|}{ Right maxilla } \\
\hline \multicolumn{4}{|c|}{ Lateral incisor } \\
\hline present & 5.9 & 26.6 & 28.2 \\
\hline absent & $11.2^{*}$ & 32.5 & 33.1 \\
\hline \multicolumn{4}{|l|}{ First molar } \\
\hline present & 7.9 & 23.0 & 23.8 \\
\hline absent & 10.2 & $32.7^{*}$ & $33.7^{*}$ \\
\hline \multicolumn{4}{|l|}{ Left maxilla } \\
\hline \multicolumn{4}{|c|}{ Central incisor } \\
\hline present & 5.6 & 23.9 & 25.0 \\
\hline absent & $11.4^{*}$ & $33.5^{*}$ & $34.3^{*}$ \\
\hline \multicolumn{4}{|l|}{ Cuspid } \\
\hline present & 6.9 & 25.0 & 26.9 \\
\hline absent & 11.0 & $33.6^{*}$ & $34.1^{\#}$ \\
\hline \multicolumn{4}{|c|}{ Left mandible } \\
\hline \multicolumn{4}{|c|}{ Second premolar } \\
\hline present & 7.5 & 24.4 & 25.6 \\
\hline absent & 10.5 & $33.0^{*}$ & $33.8^{*}$ \\
\hline \multicolumn{4}{|l|}{ First molar } \\
\hline present & 4.0 & 24.2 & 25.3 \\
\hline absent & $10.8^{*}$ & 32.0 & 32.9 \\
\hline
\end{tabular}

Table 3 Association between abnormal ECG findings and tooth absence

\begin{tabular}{|c|c|c|c|}
\hline & ST-segment depression & $\mathrm{T}$-wave abnormalities & $\begin{array}{l}\text { ST depression and/or } \\
\text { T-wave abnormalities }\end{array}$ \\
\hline \multicolumn{4}{|l|}{ Right maxilla } \\
\hline$\overline{\text { Lateral incisor }}$ & $1.937(0.880-4.261)$ & $1.491(0.949-2.343)^{\#}$ & $1.374(0.881-2.141)$ \\
\hline First molar & $1.956(0.785-4.875)$ & $1.675(0.988-2.840)^{\#}$ & $1.780(1.053-3.022)^{*}$ \\
\hline \multicolumn{4}{|l|}{$\underline{\text { Left maxilla }}$} \\
\hline Central incisor & $2.386(1.060-5.370)^{*}$ & $1.616(1.025-2.548)^{*}$ & $1.629(1.037-2.558)^{*}$ \\
\hline Cuspid & $1.692(0.823-3.480)$ & $1.612(1.041-2.495)^{*}$ & $1.503(0.978-2.312)^{\#}$ \\
\hline \multicolumn{4}{|l|}{ Left mandible } \\
\hline Second premolar & $1.860(0.813-4.257)$ & $1.601(0.985-2.603)^{\#}$ & $1.632(1.009-2.641)^{*}$ \\
\hline First molar & $3.694(1.080-12.638)^{*}$ & $1.799(1.004-3.223)^{*}$ & $1.758(0.991-3.121)^{\#}$ \\
\hline
\end{tabular}


lent in subjects with loss of the left maxillary cuspid than those with retention of this tooth. Loss of the left mandibular 2nd premolar tooth loss was also associated with a higher prevalence of $\mathrm{T}$-wave abnormalities. ST-segment depression was also more prevalent in subjects whose 1st molar in the left mandible had been lost.

The relationship between ECG findings of ST depression, T-wave abnormalities, or both and loss of each tooth was analyzed by logistic regression analysis (Table 3). After data were adjusted for gender, smoking, toothbrushing, regular doctor visits (medical or dental), serum cholesterol concentration $(\geq 220 \mathrm{mg} / \mathrm{dl}$ vs. $\leq 219 \mathrm{mg} / \mathrm{dl}$ ), serum glucose concentration ( $\geq 126 \mathrm{mg} / \mathrm{dl}$ vs. $\leq 125 \mathrm{mg} / \mathrm{dl})$, systolic BP ( $\geq 140 \mathrm{~mm} \mathrm{Hg}$ vs. $\leq 139 \mathrm{~mm} \mathrm{Hg})$, diastolic BP ( $\geq$ $90 \mathrm{~mm} \mathrm{Hg}$ vs. $\leq 89 \mathrm{~mm} \mathrm{Hg}$ ), and body mass index (BMI) ( $\geq 25 \mathrm{vs.}<25$ ), we calculated the relative risks (RRs) and $95 \%$ confidence intervals (CI) for the occurrence of abnormal ECG findings based on whether each tooth was present or absent (Table 3). In comparison with individuals who preserved their 1st molar of the right maxilla, loss of this tooth showed a significantly greater prevalence of combined ECG abnormalities. T-wave abnormalities tended to be higher in those without the lateral incisor or 1st molar in the right maxilla. Individuals with loss of the central incisor in the left maxilla had a significantly higher prevalence of ST-segment depression, T-wave abnormalities, or the combination. In individuals without the left maxillary cuspid, the prevalence of $\mathrm{T}$-wave abnormalities was significantly higher, and the combination of ECG abnormalities tended to be higher than in those who preserved this tooth. Similarly, there was a significantly higher prevalence of combined ECG abnormalities and a tendency for an increased prevalence of $T$-wave abnormalities in patients who had lost the 2nd premolar in the left mandible. The prevalence of ST-segment depression or T-wave abnormalities also was higher in subjects without the 1st molar tooth in the left mandible.

The prevalence of abnormal ECG findings was compared between groups based on the community periodontal index (CPI) codes $0,1,2,3$, and 4, after excluding the individuals with corresponding tooth loss. There were no consistent differences in the prevalence of any abnormal ECG finding among these five groups for any tooth site.

\section{Discussion}

We found a significant relationship between ECG findings and tooth loss at several specific sites. Individuals who had lost the lateral incisor or 1st molar in the right maxilla, central incisor or cuspid in the left maxilla, or 2nd premolar or 1st molar in the left mandible had a higher prevalence of ST-segment depression, T-wave abnormalities, or the combination, providing further evidence that tooth loss is associated with CHD. This relationship between tooth loss and abnormal ECG findings was significant even after adjustment for multiple confounders, indicating that specific tooth loss is an independent predictor of abnormal ECG findings in an 80-year-old population. Although tooth loss in the maxilla more than mandible, and on the left side rather than the right, tended to be related to abnormal ECG findings, the significance of this regional difference remains to be 
determined. Similarly, since tooth loss at individual sites was distributed uniformly, our findings can not exclude the possibility that there is no specific tooth site related to an abnormal ECG.

Because periodontal disease is a major cause of tooth loss in elderly individuals ${ }^{20-22)}$, and because ECG abnormalities are independent predictors of $\mathrm{CHD}^{13-15)}$, the present observations suggest that periodontal disease is an independent risk factor for CHD in octogenarians. In a prospective cohort study, tooth loss in 40 - to 75 -year-old men with periodontal disease was found to be associated with an increased risk of $\mathrm{CHD}^{23)}$. In a retrospective cohort study, the risk of fatal CHD was increased in edentulous individuals ${ }^{10}$. In a study of U.S. veterans, a significant relationship was found between the risk of $\mathrm{CHD}$ and the number of missing teeth $^{24)}$. Together with these observations, our findings support the hypothesis that tooth loss is a predictor of CHD and extend the relationship between tooth loss and CHD to an octogenarian population. We recently found ${ }^{25)}$ that the relative risk for $\mathrm{ST}$-segment depression was $10.071(\mathrm{p}<0.01)$ for edentulous patients without dentures and 3.522 (N.S.) for edentulous subjects using dentures after adjustment for various coronary risk factors, suggesting that dentures may lessen risk for CHD.

Although periodontal disease is likely to be associated with abnormal ECG findings, in the present study, grouping the patients according to CPI classification to assess periodontal status $^{26)}$ did not demonstrate a significant difference in the prevalence of abnormal ECG findings. The difference between previous studies and our study may be due to differences in patient age. Our findings indicate that CPI classification is not suitable for predicting the risk of CHD in octogenarians.

\section{Conclusion}

In the Japanese general population of 80 -year-olds, tooth loss at several sites may be an independent predictor of abnormal ECG. Even in the very elderly population, tooth loss and periodontal disease is an independent risk factor for CHD.

\section{References}

1) Mattila, K. J., Valle, M. S., Nieminen, M. S., Valtonen, V. V. and Hietaniemi, K. L.: Dental infections and coronary atherosclerosis. Atherosclerosis 103: 205-211, 1993.

2) DeStefano, F., Anda, R. F., Kahn, H. S., Williamson, D. F. and Russell, C. M.: Dental disease and risk of coronary heart disease and mortality. Br. Med. J. 306:688-691, 1993.

3) Beck, J. D. and Slade, G. D.: Epidemiology of periodontal diseases. Curr. Opin. Periodontol. 3: 3-9, 1996.

4) Beck, J. D., Garcia, R., Heiss, G., Vokonas, P. S. and Offenbacher, S.: Periodontal disease and cardiovascular disease. J. Periodontol. 67: 1123-1137, 1996.

5) Kinane, D. F.: Periodontal diseases' contributions to cardiovascular disease: an overview of potential mechanisms. Ann. Periodontol. 3: 142-150, 1998.

6 ) Beck, J. D., Offenbacher, S., Williams, R., Gibbs, P. and Garcia, R.: Periodontitis: a risk factor for coronary heart disease? Ann. Periodontol. 3: 127-141, 1998.

7) Beck, J. D., Pankow, J., Tyroler, H. A. and Offenbacher, S.: Dental infections and atherosclelosis. 
Am. Heart J. 138: S528-533, 1999.

8 ) Arbes, S. J. Jr, Slade, G. D. and Beck, J. D.: Association between extent of periodontal attachment loss and self-reported history of heart attack: an analysis of NHANES III data. J. Dent. Res. 78: 1777-1782, 1999.

9) Mattila, K. J., Valtonen, V. V., Nieminen, M. and Huttunen, J. K.: Dental infection and the risk of new coronary events: prospective study of patients with documented coronary artery disease. Clin. Infect. Dis. 20: 588-592, 1995.

10) Morrison, H. I., Ellison, L. F. and Taylor, G. W.: Periodontal disease and risk of fatal coronary heart and cerebrovascular diseases. J. Cardiovasc. Risk 6: 7-11, 1996.

11) Seymour, R. A. and Steele, J. G.: Is there a link between periodontal disease and coronary heart disease? Br. Dent. J. 184: 33-38, 1998.

12) Takata, Y., Ansai, T., Matsumura, K., Awano, S., Hamasaki, T., Sonoki, K., Kusaba, A., Akifusa, S. and Takehara, T.: Relationship between tooth loss and electrocardiographic abnormalities in octogenarians. J. Dent. Res. 80: 1648-1652, 2001.

13) Liao, Y., Liu, K., Dyer, A., Schoenberger, J. A., Shekelle, R. B., Collette, P. and Stamler, J.: Sex differential in the relationship of electrocardiographic ST-T abnormalities to risk of coronary death: 11.5 year follow-up findings of the Chicago Heart Association Detection Project in Industry. Circulation 75: 347-352, 1987.

14) Menotti, A. and Seccareccia, F.: Electrocardiographic Minnesota code findings predicting short-term mortality in asymptomatic subjects. The Italian RIFLE Pooling Project (Risk Factors and Life Expectancy). G. Ital. Cardiol. 27: 40-49, 1997.

15) De Bacquer, D., De Backer, G., Kornitzer, M. and Blackburn, H.: Prognostic value of ECG findings for total, cardiovascular disease, and coronary heart disease death in men and women. Heart $80: 570-577,1998$.

16) Kwok, J. M., Miller, T. D., Christian, T. F., Hodge, D. O. and Gibbons, R. J.: Prognostic value of a treadmill exercise score in symptomatic patients with nonspecific ST-T abnormalities on resting ECG. J.A.M.A. 282: 1047-1053, 1999.

17) Crenshaw, J. H., Mirvis, D. M., el-Zeky, F., van der Zwaag. R., Ramanathan, K. B., Maddock, V., Kroetz, F. H. and Sullivan, J. M: Interactive effects of ST-T wave abnormalities on survival of patients with coronary artery disease. J. Am. Coll. Cardiol. 18: 413-420, 1991.

18) Tervahauta, M., Pekkanen, J., Punsar, S. and Nissinen, A.: Resting electrocardiographic abnormalities as predictors of coronary events and total mortality among elderly men. Am. J. Med. $100: 641-645,1996$.

19) Abdalla, I. S., Prineas, R. J., Neaton, J. D., Jacobs, D. R. Jr and Crow, R. S.: Relation between ventricular premature complexes and sudden cardiac death in apparently healthy men. Am. J. Cardiol. 60: 1036-1042, 1987.

20) Ong, G.: Periodontal reasons for tooth loss in an Asian population. J. Clin. Periodontol. 23: 307-309, 1996.

21) Ong, G.: Periodontal diseases and tooth loss. Int. Dent. J. 48 (Suppl 1) : 233-238, 1998.

22) Stabholz, A., Babayof, I., Mersel, A. and Mann, J.: The reasons for tooth loss in geriatric patients attending two surgical clinics in Jerusalem, Israel. Gerontology 14: 83-88, 1997.

23) Joshipura, K. J., Rimm, E. B., Douglass, C. W., Trichopoulos, D., Ascherio, A. and Willett, W. C.: Poor oral health and coronary heart disease. J. Dent. Res. 75: 1631-1636, 1996.

24) Loesche, W. J., Schork, A., Terpenning, M. S., Chen, Y. M., Dominguez, B. L. and Grossman, N.: Assessing the relationship between dental disease and coronary heart disease in elderly $\mathrm{U}$. S. veterans. J. Am. Dent. Assoc. 129: 301-311, 1998.

25) Takata, Y.: Association of poor dentition status in the elderly with electrocardiographic ST 
segment depression. J. Dent. Res. 80:2042 (letter), 2001.

26) Darout, I. A., Albandar, J. M. and Skaug, N.: Periodontal status of adult Sudanese habitual users of miswak chewing sticks or toothbrushes. Acta Odontol. Scand. 58: 25-30, 2000.

\section{Sources of support :}

This work was supported in part by Grants-in-Aid for Scientific Research (B) 11557162 and (C) 12671959, from the Ministry of Education, Culture, Sports, Science and Technology of Japan.

\section{0 歳者における個々の歯牙啔失と異常心電図所見の関係}

\begin{tabular}{|c|c|c|c|c|c|c|c|c|}
\hline 田 & & 豊1 & - 安 & 細 & 敏 & 弘 $^{2}$ & • 粟 & 野 \\
\hline 木 & 一 & 男 $^{1}$ & - 秋 & 房 & 住 & 郎 ${ }^{2}$ & - 福 & 原 \\
\hline 坂 & 正 & 則 $\left.\right|^{1}$ & - 竹 & 原 & 直 & 道 ${ }^{2}$ & & \\
\hline
\end{tabular}

平成 17 年 7 月 25 日受付

平成 17 年 8 月 26 日受理

抄録

冠動脈疾患と個々の歯牙啔失の関係について福岡県 80 歳住民を対象に調查を行った. 福岡県内の 9 市町村区に住 屯 1282 名の 80 歳住民のうち, 697 名が健診を受けた。健診では歯科健診, 十二誘導心電図, 問診, 採血, 血圧測定


臼歯の垡失がある住民では，こ扎らの歯牙の喪失がない住民よりあ，心電図の ST 低下か T波異常かこの心電図異常 のどちらかの発現頻度が高かった。この関係はロジスティック回帰分析を用いて性差, 喫煙, 歯磨き, 医院通院, 血 清コレステロール值, 血糖値, 血圧值, BMI で補正しても同様であった. 以上の結果から, 80 歳高齢者において, こ れらの部位の歯牙培失が ST 低下やT波異常の心電図異常之独立した関係にあり, 虚血性心臟病の危険因子となる可 能性が示唆された。

キーワード : 心電図/歯牙患失/歯科/冠動脈疾患/高齢者 